\title{
SPRAY DRYING OF GRAPE JUICE FROM HYBRID CV. BRS VIOLETA: MICROENCAPSULATION OF ANTHOCYANINS USING PROTEIN/MALTODEXTRIN BLENDS AS DRYING AIDS
}

\author{
POLIANA MOSER, ${ }^{1,3}$ REGINALDO TEODORO DE SOUZA ${ }^{2}$ and VÂNIA REGINA NICOLETTI TELIS ${ }^{1}$ \\ ${ }^{1}$ Food Engineering and Technology Department, São Paulo State University, São José do Rio Preto, Brazil \\ ${ }^{2}$ Brazilian Agriculture Research Company, Grape and Wine National Research Center, Tropical Viticulture Experimental Station, Jales, Brazil
}

${ }^{3}$ Corresponding author.
TEL: +55 $173221-2255 ;$
FAX: +55 $173221-2299 ;$
EMAIL: polianamoser@yahoo.com.br

Received for Publication August 17, 2015 Accepted for Publication January 8, 2016

doi:10.1111/jfpp.12852

\begin{abstract}
Grape juice contains high amounts of anthocyanins, with great potential for substituting synthetic food dyes. Carrier agents used in spray drying entraps anthocyanins, allowing their preservation. This work appraised whey protein/ maltodextrin (WM) and soy protein/maltodextrin (SM) blends as alternative carriers for spray drying of grape juice and encapsulation of anthocyanins. The effects of carrier agent concentration (CAC) and ratio protein/carrier agent $(R)$ on grape juice powder properties were evaluated. The grape juice powders presented good solubility, low water content and high anthocyanin retention. WM blends resulted in higher yields and higher anthocyanin retention (from 77.9 to 94\%) than SM blends, whereas SM blends leaded to higher encapsulation efficiency (>97\%). Increasing CAC and $R$ resulted in brighter powders, but reconstituted juices presented color parameters similar to those of fresh juice. WM and SM were suitable for encapsulating anthocyanins of grape juice, resulting in powders with potential applications in food industry.
\end{abstract}

\section{PRACTICAL APPLICATIONS}

The grape cultivar BRS violeta contains high levels of anthocyanins and is an alternative to produce antioxidant-rich and highly colored grape juice. Spray drying is applied for producing powdered grape juice with high anthocyanin content. In this technique, the addition of whey and soy proteins blended with maltodextrin as carrier agents avoid problems such as stickiness, which is negative to process yield and product quality. Moreover, the use of carrier agents in spray drying promotes the microencapsulation of bioactive compounds, allowing their protection and preservation during processing and storage. The grape juice powder from cv. BRS Violeta can be applied in the food industry as a potential substitute for synthetic food dyes, in addition to being a promising additive for incorporating anthocyanins into functional foods.

\section{INTRODUCTION}

Grapes and their derived products are important natural sources of phenolic compounds. EMBRAPA Grape \& Wine (Brazilian Corporation of Agricultural Research, Unit Grape \& Wine) developed the hybrid cultivar BRS Violeta ("BRS Rubea" X "IAC 1398-21") in 2006. This cultivar contains high levels of anthocyanins and is an alternative to produce highly colored and antioxidant-rich grape juice, as well as dehydrated products with potential use as dietary supplements (Camargo et al. 2005). Rebello et al. (2013) found $3,950 \mathrm{mg}$ of anthocyanins $/ \mathrm{kg}$ of grape BRS Violeta (expressed as malvidin 3.5-diglucoside equivalents).

Powdered fruit juices are good alternatives of convenient and healthy ingredients to formulated foods. Powdered juices rich in natural pigments are potential substitutes for synthetic food dyes, allowing their use with double 
TABLE 1. SAMPLE FORMULATIONS CORRESPONDING TO THE EXPERIMENTAL DESIGN AND RESPECTIVE RESULTS OF PROCESS YIELD, SOLUBILITY, ANTHOCYANIN RETENTION AND ENCAPSULATION EFFICIENCY

\begin{tabular}{|c|c|c|c|c|c|c|}
\hline Sample* & $\mathrm{CAC}^{+}$ & $R(\%)^{\dagger}$ & Yield (\%) & Solubility (\%) & Anthocyanin retention (\%) & $\mathrm{EE}(\%)$ \\
\hline 1WM & $0.25(-1)$ & $10(-1)$ & 41.47 & 92.91 & 80.01 & 62.81 \\
\hline 2WM & $0.25(-1)$ & $30(+1)$ & 57.22 & 93.1 & 87.8 & 69.48 \\
\hline 3WM & $0.75(+1)$ & $10(-1)$ & 75.48 & 96.96 & 83.61 & 78.77 \\
\hline 4WM & $0.75(+1)$ & $30(+1)$ & 74.59 & 91.91 & 91.31 & 80.2 \\
\hline 5WM & $0.15(-1.41)$ & $20(0)$ & 3.15 & 96.13 & 77.89 & 84.1 \\
\hline 6WM & $0.85(+1.41)$ & $20(0)$ & 74.75 & 93.96 & 94.04 & 81.14 \\
\hline 7WM & $0.5(0)$ & $5.86(-1.41)$ & 75.58 & 96.51 & 86.67 & 68.19 \\
\hline 8WM & $0.5(0)$ & $34.14(+1.41)$ & 74.25 & 92.72 & 83.66 & 72.25 \\
\hline 9WM & $0.5(0)$ & $20(0)$ & 74.27 & 93.33 & 88.86 & 72.27 \\
\hline 10WM & $0.5(0)$ & $20(0)$ & 72.58 & 94.68 & 85.54 & 78.47 \\
\hline $1 \mathrm{SM}$ & $0.75(-1)$ & $10(-1)$ & 49.31 & 94.25 & 60.87 & 97.12 \\
\hline $2 \mathrm{SM}$ & $0.75(-1)$ & $30(+1)$ & 48.93 & 91.26 & 58.49 & 97.1 \\
\hline 3SM & $1.25(+1)$ & $10(-1)$ & 51.53 & 95.03 & 63.96 & 98.86 \\
\hline $4 S M$ & $1.25(+1)$ & $30(+1)$ & 51.74 & 88.69 & 63.82 & 99.11 \\
\hline $5 S M$ & $0.65(-1.41)$ & $20(0)$ & 49.41 & 91.21 & 62.42 & 97.41 \\
\hline $6 S M$ & $1.35(+1.41)$ & $20(0)$ & 47.48 & 88.92 & 67.46 & 99.17 \\
\hline 7SM & $1(0)$ & $5.86(-1.41)$ & 55.40 & 94.93 & 71.61 & 98.48 \\
\hline 8SM & $1(0)$ & $34.14(+1.41)$ & 56.12 & 87.43 & 63.33 & 97.76 \\
\hline 9SM & $1(0)$ & $20(0)$ & 54.25 & 91.47 & 64.12 & 97.43 \\
\hline $10 \mathrm{SM}$ & $1(0)$ & $20(0)$ & 53.05 & 91.56 & 60.76 & 98.19 \\
\hline
\end{tabular}

* WM: blends of whey protein concentrate/maltodextrin; SM: blends of soy protein isolate/maltodextrin.

+ CAC: $g$ of carrier agent/g of soluble solids of the juice; $R(\%)$ : $g$ dry protein/100 $\mathrm{g}$ dry carrier agent.

functionality: promoting food coloring and providing health benefits through their bioactive properties (Wrolstad and Culver 2012).

Spray drying is an alternative for producing powdered grape juice with high anthocyanin content, although anthocyanins are unstable and losses can occur during drying, reducing nutritional and functional attributes of the juice (Tonon et al. 2010). In addition, spray drying of fruit juices is difficult due to their hygroscopic and thermoplastic behavior at high temperature and humidity, a consequence of their high content of sugars and organic acids with low molar mass (Adhikari et al. 2004). Spray dried powders with low molar mass compounds are usually in an amorphous, nonequilibrium state that is very sensitive to changes in temperature and water content, being susceptible to glass transition related changes, including stickiness, caking, and color changes (Telis and Martínez-Navarrete 2010).

The use of drying aids to entrap an active agent in a biopolymer matrix, protecting it against unfavorable environmental conditions, is an important strategy to allow spray drying of foods susceptible to degradation or water plasticization. The encapsulating matrix protects sensitive ingredients during storage, preserves flavors, protects food against nutritional losses and may add nutritive materials to food after processing, providing additional attractiveness for the products (Phisut 2012).

In general, maltodextrins and gum Arabic are drying adjuvants in spray drying of fruit juices (Telis and Martínez-
Navarrete 2012). Maltodextrins are inexpensive, have widespread use in foods, possess low viscosity at high solid content, and good solubility. Gum Arabic, despite the suitable properties that have facilitated its extensive use as carrier agent, is an expensive ingredient with availability and costs subjected to fluctuation, which have motivated research for alternative encapsulation matrices (Madene et al. 2006). Whey and soy proteins are widely available, natural ingredients with high nutritional value. They have good properties for encapsulation, such as emulsification, solubility, film forming, and water binding capacity (Molina Ortiz et al. 2009; Bastos et al. 2012).

The efficacy of maltodextrin as drying adjuvant is due to its rapid film forming property and low water diffusivity in these films. On the other hand, proteins form smooth and nonsticky films much earlier than maltodextrin, and powder recovery is higher when a small amount of protein is added to the spray dried solution (Adhikari et al. 2009). Maltodextrin/ protein blends favor protection of bioactive compounds and present good drying properties (Nesterenko et al. 2013a). Fang and Bhandari (2012) observed that a small amount of whey protein $(1 \%)$ is required to dry fruit juices, while large amounts of maltodextrin $(>30 \%)$ are needed for the same purpose, pointing out that addition of large carrier amounts increases cost and may alter product flavor and taste.

Microencapsulation of anthocyanins using maltodextrins (Tonon et al. 2010; Ferrari et al. 2012), whey proteins (Fang and Bhandari 2012) and soy proteins (Robert et al. 2010) has 
been investigated, however application of maltodextrin mixtures with whey or soy proteins as drying aids for anthocyanins has been barely reported. Based on these considerations, this study aimed to investigate the potential of maltodextrin blends with whey or soy proteins as carrier agents for encapsulation of grape juice anthocyanins by spray drying.

\section{MATERIAL AND METHODS}

\section{Materials}

Fresh grapes (Vitis labrusca, cv. BRS Violeta) were provided by EMBRAPA Grape and Wine (Jales, Brazil). Maltodextrin DE-10 (Mor-Rex 1910, Corn Products, Brazil), whey protein concentrated (WPC) (WPC80, Alibra, Brazil) and soy protein isolate (SPI) (Supro 783, Tovani Benzaquen, Brazil) were the carrier agents.

\section{Grape Juice Preparation}

A batch of juice was processed from fresh grapes by steam extraction (60 $\mathrm{min}, 75-85 \mathrm{C}$ ), sieved (270 mesh) to remove potassium bitartrate crystals, and stored at $-18 \mathrm{C}$ until use. The juice had total solid content of $15.18 \pm 0.02 \mathrm{~g} / 100 \mathrm{~g}$ $(\mathrm{w} / \mathrm{w}), \quad 14.0 \pm 0.1 \quad{ }^{\circ}$ Brix, $\mathrm{pH} \quad 3.84 \pm 0.006$, sugar $123.25 \pm 17.77 \mathrm{~g} / \mathrm{L}$, acidity (\% tartaric acid) of $0.60 \pm 0.004$, ash $0.43 \pm 0.004 \mathrm{~g} / 100 \mathrm{~g}(\mathrm{w} / \mathrm{w})$, and 1,405.50 $\pm 3.74 \mathrm{mg} / \mathrm{L}$ total anthocyanins (Francis 1982).

\section{Sample Preparation}

Blends of WPC/maltodextrin (WM) and SPI/maltodextrin (SM) used as carriers were added to juice at different ratios of carrier agent concentration to soluble solids of juice (CAC), and at different ratios of protein to total carrier agent $(R)$. Experiments followed a $2^{2}$ rotatable central composite design (Table 1 ).

Carriers were added to juice under agitation, until complete dissolution. The effects of CAC and $R$ on yield, water content, solubility, anthocyanin retention, color and encapsulation efficiency of powdered juice were evaluated by response surface methodology, applying analysis of variance (ANOVA) at 5\% probability.

\section{Spray Drying}

Spray drying was performed in a concurrent spray dryer (B290, Büchi, Switzerland), with spray nozzle (orifice diameter $=0.7 \mathrm{~mm}$ ), operating at: inlet air temperature $=140 \mathrm{C}$; feed flow rate $=2 \mathrm{~mL} / \mathrm{min}$; air flow rate $=500 \mathrm{~L} / \mathrm{h}$. The grape juice powders obtained were packed into metallized plastic bags. The bags were then stored in a desiccator containing silica gel until evaluation. Drying yield was calculated as the ratio between total solids recovered and solids present in juice before drying.

\section{Characterization of Powdered Juice}

Water Content. Powder water content was determined gravimetrically, drying samples in vacuum oven (70C) until constant weight.

Solubility. Powder samples $(1 \mathrm{~g})$ were added to $100 \mathrm{~mL}$ of distilled water, agitated for $5 \mathrm{~min}$, and centrifuged $(3,000 \times \mathrm{g}$, $5 \mathrm{~min})$. Aliquots $(25 \mathrm{~mL})$ of the supernatant were transferred to weighed Petri dishes and oven dried (105C, $5 \mathrm{~h}$ ). Solubility (\%) was calculated as the weight difference (Cano-Chauca et al. 2005).

Anthocyanin Retention. Powder samples (0.05 g) were extracted with $95 \%$ ethanol/1.5 N HCl (85:15, v:v), vortexed for $5 \mathrm{~min}$ and brought to $50 \mathrm{~mL}$ with the extracting solution. Samples were protected from light and refrigerated (4C, $12 \mathrm{~h}$ ) (Francis 1982). Absorbance was measured in UV-vis spectrophotometer (SP-220, Biospectro) at $520 \mathrm{~nm}$, and total anthocyanin content was calculated using molar absorbance $[28,000 \mathrm{~L} /(\mathrm{mol} \mathrm{cm})]$ and molar mass [493.5 g/ mol] corresponding to malvidin-3-glucoside (Wrolstad 1993). Anthocyanin retention was calculated as the ratio between total anthocyanin content (mg/100 g of dry matter) in powder and in juice before drying.

\section{Encapsulation Efficiency of Anthocyanins}

(EE). Powder samples $(0.2 \mathrm{~g})$ were washed with $10 \mathrm{~mL}$ of ethanol $99.5 \%$ to extract unencapsulated anthocyanins without capsule disruption (Nori et al. 2011). The mixture was stirred for one minute, filtered, and the supernatant was analyzed for anthocyanins as described in anthocyanin retention. Encapsulation efficiency was calculated as:

$$
\mathrm{EE}(\%)=\frac{W 2-W 1}{W 2}
$$

in which $W 1=$ anthocyanins in the supernatant and $W 2=$ total anthocyanins in the powder.

Color. CIELab coordinates $\left(L^{\star}, a^{\star}, b^{\star}\right)$ were measured using a Hunter Lab colorimeter (Color Flex EZ, The United States), with D65 illuminant and $10^{\circ}$ observation angle. Hue angle $\left(h^{\star}\right)$, chroma $\left(C^{\star}\right)$ and total color differences $\left(\Delta E^{\star}\right)$ between fresh grape juice and powdered juice after reconstitution in water were calculated by Eqs. (2-4) (Telis and Martínez-Navarrete 2010). 
TABLE 2. ANALYSIS OF VARIANCE (ANOVA) OF THE MATHEMATICAL MODELS FOR YIELD (FOR SAMPLES PRODUCED WITH WM AND SM BLENDS) AND ENCAPSULATION EFFICIENCY (FOR SAMPLES PRODUCED WITH SM BLEND)

\begin{tabular}{|c|c|c|c|c|}
\hline Source of variation & Sum of squares & Degrees of freedom & Mean square & F calculated \\
\hline & Yield WM & & & \\
\hline Regression & $4,494.09$ & 1 & 4494.09 & 70.17 \\
\hline Residue & 512.35 & 8 & 64.04 & \\
\hline \multirow[t]{2}{*}{ Total SS } & $5,006.44$ & 9 & & \\
\hline & Yield SM & & & \\
\hline Regression & 61.14 & 1 & 61.14 & 28.82 \\
\hline Residue & 16.97 & 8 & 2.12 & \\
\hline \multirow[t]{2}{*}{ Total SS } & 78.11 & 9 & & \\
\hline & EE SM & & & \\
\hline Regression & 4.87 & 1 & 4.87 & 38.21 \\
\hline Residue & 1.02 & 8 & 0.13 & \\
\hline Total SS & 5.89 & 9 & & \\
\hline
\end{tabular}

Value $F$ critical $=5.32$

$$
\begin{gathered}
h^{*}=\operatorname{arctg}\left(\frac{b *}{a *}\right) \\
C^{*}=\sqrt{\left(a^{*}\right)^{2}+\left(b^{*}\right)^{2}} \\
\Delta E^{*}=\sqrt{\left(\Delta L^{*}\right)^{2}+\left(\Delta a^{*}\right)^{2}+\left(\Delta b^{*}\right)^{2}}
\end{gathered}
$$

For reconstitution, juice powder was mixed with distilled water keeping always the same proportion between solids coming from fresh juice and water. As fresh juice presented $14^{\circ} \mathrm{Brix}$, the mass of powder was calculated to give a ratio of $14 \mathrm{~g}$ of solids from juice to $86 \mathrm{~g}$ of water.

\section{Scanning Electron Microscopy (SEM)}

Powder samples were attached to double-sided adhesive tape mounted on SEM stubs, covered with gold layer $(9 \mathrm{~nm})$ under vacuum, and observed in scanning electronic microscope (FEI - Inspect S50) working at $5 \mathrm{kV}$, with $1,000 \times$ and $5,000 \times$ of magnification.

\section{Particle Size Distribution}

Particle size distribution was analyzed by laser light scattering (LA-900, Horiba Instruments, Inc., Japan). Sample amount was adjusted to obtain refractive reading unit.

\section{RESULTS AND DISCUSSION}

The drying yield, solubility, anthocyanin retention, and encapsulation efficiency of juice powders produced with different CAC and $R$ (Table 1) presented different behaviors for blends WM and SM, and the mathematical models obtained for each response were tested for adequacy and fitness using ANOVA only considering the significant terms $(P<0.05)$. The results for models describing yield (for samples WM and SM) and encapsulation efficiency (for samples SM) indicate that these were adequate, showing significant regression, low residual values, no lack of fit and satisfactory coefficients of determination (Table 2).

Despite all the responses evaluated had shown higher $F$-calculated values compared with critical values, the coefficients of determination for anthocyanin retention (in samples WM) and solubility (in samples WM and SM) were not satisfactory, hindering generation of predictive models and response surfaces.

\section{Yield}

Independently of the protein used, the carrier agent concentration $(\mathrm{CAC})$ presented significant effect $(P<0.05)$ on drying yield (Tables 1 and 2), whereas the ratio of protein/total carrier agent $(R)$ did not affect yield significantly.

In samples WM, values of CAC in the range of $0.5-0.85 \mathrm{~g}$ of carrier agent/g of soluble solids of juice resulted in the highest powder recovery, around $75 \%$ (Fig. 1). The

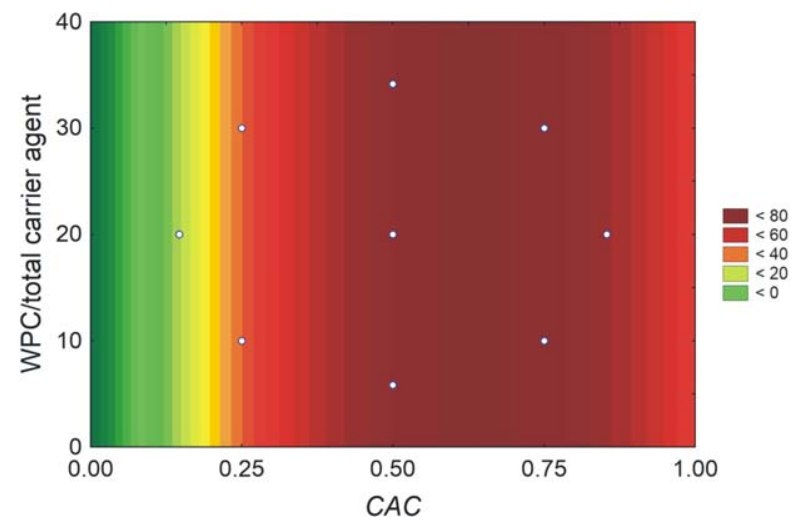

FIG. 1. CONTOUR PLOT FOR SPRAY DRYING YIELD OF GRAPE JUICE POWDER USING DIFFERENT VALUES OF CARRIER AGENT CONCENTRATION (CAC) AND WPC/TOTAL CARRIER AGENT RATIO 
proposed model to represent yield for blends WM (Eq. 5) showed $R^{2}$ of 0.89 .

$$
\text { Yield }(\%)_{\mathrm{WM}}=75.78+19.08 \mathrm{CAC}-16.80 \mathrm{CAC}^{2}
$$

According to Fang and Bhandari (2012), 30\% of maltodextrin is a minimum amount to efficient spray drying (criteria of $50 \%$ powder recovery) of fruit juices. In the present study, using CAC $=0.25$ ( $25 \%$ of carrier in relation to juice soluble solids) resulted in yield of $57 \%$ (Table 1), demonstrating that addition of a small amount of WPC to maltodextrin improved spray drying of grape juice. On the other hand, the lowest level of carrier agent concentration $(\mathrm{CAC}=0.15)$ resulted in very low yield $(3.15 \%)$, which is not acceptable. Bustos-Garza et al. (2013) used whey protein to microencapsulate astaxanthin oleoresin and obtained yield of $63 \%$, which was lower than that found in this study for WPC/maltodextrin blends.

Powder losses during drying may have resulted from a combination of powder deposition on dryer chamber, which commonly occurs in sugar-rich foods due to stickiness, as well as from pumping out of fine particles through the dryer filter (Fang et al. 2013).

Using blends SM resulted in yields varying from 47.5 to $56.1 \%$. Using $\mathrm{CAC}=1$, independently of the SPI/total carrier agent ratio, resulted in the highest yield. When using higher or lower values of CAC, powder recovery decreased. These results indicate that, for the drying conditions applied in this study, the optimal CAC for blends SM was $1 \mathrm{~g}$ of carrier agent/g of soluble solids of grape juice. Nesterenko et al. (2012), using soy protein in the microencapsulation of $\alpha$ using soy obtained yield of $83 \%$, which was greater than the maximum yield found in this study. The obtained model (Eq. 6) was also suitable for prediction of yield using blends $\mathrm{SM}\left(R^{2}=0.78\right)$.

$$
\text { Yield }(\%)_{\mathrm{SM}}=54.37-3.30 \mathrm{CAC}^{2}
$$

\section{Water Content}

Powders obtained with blends WM showed water contents from 0.79 to $5.26 \%$ (dry basis), whereas for blends SM moisture varied from 0.60 to $2.86 \%$ (dry basis). For both carrier blends, water content of juice powder was not affected by CAC or $R$, and most of formulations resulted in water contents lower than $5 \%$, a characteristic limit to water content proposed for spray dried products (Fang et al. 2013).

\section{Solubility}

Grape juice dried with protein/maltodextrin blends presented high solubility. In samples WM powder solubility varied from 92 to $97 \%$, while for blend SM it was slightly lower, ranging from 87 to $95 \%$ (Table 1). Using maltodextrin as carrier, Cano-Chauca et al. (2005) also noted high solubility of powdered mango juice $(>90 \%)$.

Powder solubility was not influenced by CAC, which is in agreement with Kha et al. (2010) that studied production of gac powder using maltodextrin. According to Phisut (2012), increasing maltodextrin concentration did not reduced powder solubility. This effect may be explained by the high water solubility of maltodextrin. Yousefi et al. (2011) reported that solubility is strongly affected by carrier type and, in some cases, by carrier concentration.

Powder solubility was negatively influenced by increasing $R$, although the obtained models were not predictive. Nevertheless, reduction in solubility was small and all systems showed good characteristics of rehydration. Frequently, the functional properties of proteins are limited by their relatively poor solubility, particularly close to the isoelectric point (pI). Whey protein has $\mathrm{pI}$ at $\mathrm{pH}$ near 5.0 (Duongthingoc et al. 2013) and soy protein near 4.5 (Wang et al. 2010).

\section{Anthocyanin Retention}

Anthocyanin retention was greatly affected by the protein used with maltodextrin (Table 1). In samples WM, the retention was higher, varying from 77.9 to $94 \%$, whereas powders produced with blends SM retained between 58.5 and $71.6 \%$ of anthocyanins present in the juice before drying. Nayak and Rastogi (2010) reported similar values to anthocyanin retention using maltodextrin as drying aid (65.1-79.8\%).

Despite mathematical models obtained for anthocyanin retention could not be considered predictive due to low coefficient of determination, in samples WM there was a trend that larger values of CAC resulted in greater anthocyanin retention. On the other hand, in blends SM, CAC did not affect the pigment retention. The ratio $R$ did not influence anthocyanin retention either for WPC or for SPI.

In samples dried with SM, even using higher values of CAC in relation to blends WM, there was lower anthocyanin retention. The solid level is an important parameter influencing core retention in encapsulated systems. This influence could be explained by reduction of core molecule mobility when entrapped in the wall material, in addition to lower time needed to form the protective shell, both induced by higher solid content. However, over a critical solid concentration an abrupt increase in viscosity may occur, leading to significant fall in encapsulation efficiency (Nesterenko et al. 2013b). 


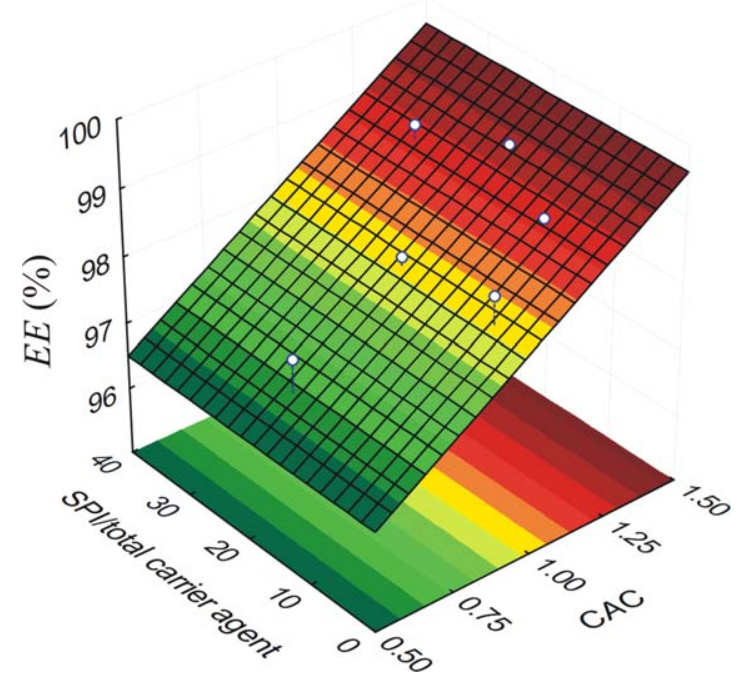

FIG. 2. INFLUENCE OF CARRIER AGENT CONCENTRATION (CAC) AND SPI/TOTAL CARRIER AGENT RATIO IN ENCAPSULATION EFFICIENCY (EE) OF ANTHOCYANINS IN GRAPE JUICE POWDER

\section{Encapsulation Efficiency}

In general, both carrier blends resulted in adequate encapsulation of anthocyanins, although SM blends resulted in higher EE than WM blends, indicating better encapsulating ability of soy protein (Table 1). In samples WM, CAC and R did not significantly influence EE. Powders presented $62.8 \% \leq \mathrm{EE} \leq 84.1 \%$, demonstrating the fair ability of these carrier formulations to encapsulate anthocyanins of grape juice. Lim et al. (2012) reported EE of $90.12 \%$ for pitaya seed oil encapsulated with whey protein/maltodextrin. MillqvistFureby et al. (2001), using only WPC to stabilize emulsions of canola oil, found that EE decreased with increasing protein denaturation and observed that poor encapsulation may be due to less flexible protein structure after denaturation.

In samples SM, EE was higher, varying from 97.10 to $99.17 \%$, increasing significantly $(P<0.05)$ with increasing CAC (Fig. 2). The mathematical model (Eq. 7) obtained for EE showed $R^{2}=0.83$, being predictive (Table 2). The ratio $R$ in systems WM and SM did not affect EE of anthocyanins in powdered juice.

$$
\mathrm{EE}(\%)_{\mathrm{SM}}=98.06+0.78 \mathrm{CAC}
$$

Higher amounts of carrier result in faster polymer precipitation on the dispersed phase surface, preventing core diffusion across phase boundary. Furthermore, increasing viscosity of the solution delays core diffusion within polymer droplets (Jyothi et al. 2010). The excellent encapsulation of anthocyanins with higher concentrations of SM blend is consistent with the results of SEM, which indicated that increasing CAC resulted in formation of more spherical particles.
Using soy protein, Robert et al. (2010) observed that EE reached higher values for anthocyanins than polyphenol, showing the ability of this carrier to bind anthocyanins, which could be related to the flavylium cation of anthocyanins. Deng et al. (2014), using only soy protein or soy protein/ starch blend, also found that EE varied considerably with composition of encapsulating materials. Robert et al. (2010) reported greater EE of anthocyanins using soy protein (35.8$100 \%)$ and maltodextrin (89.4-100\%) as wall materials.

\section{Color}

Color characteristics of powdered juice were affected by CAC and by $R$. The mathematical models obtained to $L^{*}$, $C^{\star}$, and $h^{\star}$ for samples WM and SM were predictive according to ANOVA (Table 3). Surface plots based on generated models (Eqs. 8-13) are shown in Fig. 3.

Lightness $\left(L^{*}\right)$ was significantly affected $(P<0.05)$ by both CAC and $R$. The response models Eq. (8) with $R^{2}=0.98$, and Eq. (9), with $R^{2}=0.90$, to first and second model presented below, indicate that increasing $\mathrm{CAC}$ and $\mathrm{R}$ resulted in brighter powders (Fig. 3A and B). The increase in lightness is due to the dilution effect caused by carrier addition to juice, resulting in loss of color. Similar results were found to powdered juice of açai (Tonon et al. 2009), gac fruit (Kha et al. 2010) and blackberry (Ferrari et al. 2012), microencapsulated with maltodextrin. The juice dried with SM presented higher values of $L^{\star}$ (45.38-64.34) than WM (31.57-57.77), probably because of the largest amount of carrier.

$$
\begin{gathered}
L_{\mathrm{WM}}^{*}=50.36+8.30 \mathrm{CAC}-2.96 \mathrm{CAC}^{2}+2.29 R \\
L_{\mathrm{SM}}^{*}=55.94+5.61 \mathrm{CAC}+2.55 R \\
C_{\mathrm{SM}}^{*}=22.76-1.83 \mathrm{CAC}-1.58 R \\
C_{\mathrm{SM}}^{*}=19.46-2.86 \mathrm{CAC}-2.03 R \\
h_{\mathrm{WM}}^{*}=323.96-6.95 \mathrm{CAC}-3.28 R \\
h_{\mathrm{SM}}^{*}=314.90-4.43 \mathrm{CAC}-4.70 R
\end{gathered}
$$

Values of chroma (in the range of 19.23-26.73 for WM, and 13.72-24.77 for SM) and hue (varying from 313.1 to 335.8 for WM, and 305.7 to 324.3 for SM) of juice powder were located in the fourth quadrant of CIELab color chart, corresponding to purple color. Increasing values of CAC and $R$ decreased $C^{\star}$ (Fig. 3C and $\mathrm{D}$ ), indicating grayish chromaticity, whereas higher chroma values at low CAC and $R$ demonstrate more saturated or vivid color. Similar findings were reported by Kha et al. (2010). Increasing CAC and $R$ also leaded to decrease in $h^{*}$ (Fig. $3 \mathrm{E}$ and F), which means that color became more blue-purple than red-purple. Comparison of $h^{*}$ between powdered and fresh grape juice $\left(h^{*}=355.8\right)$ shows that carrier addition resulted in lower 


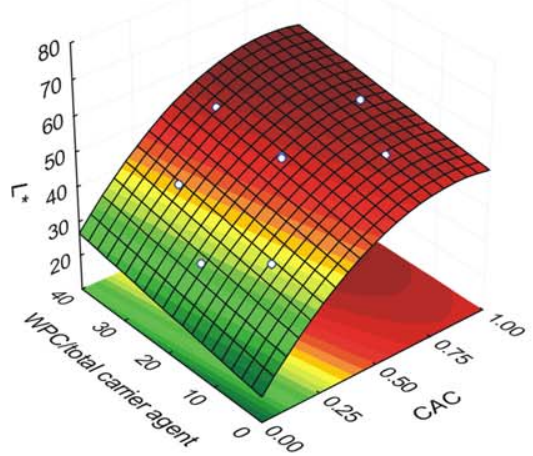

(a)

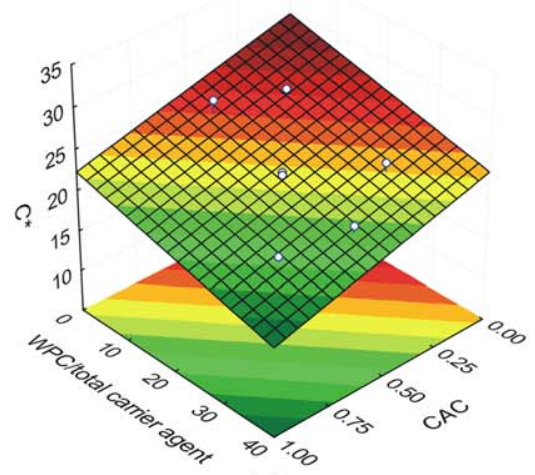

(c)

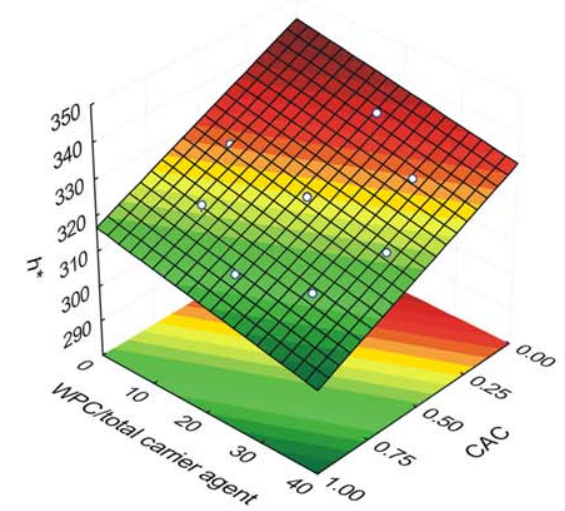

(e)

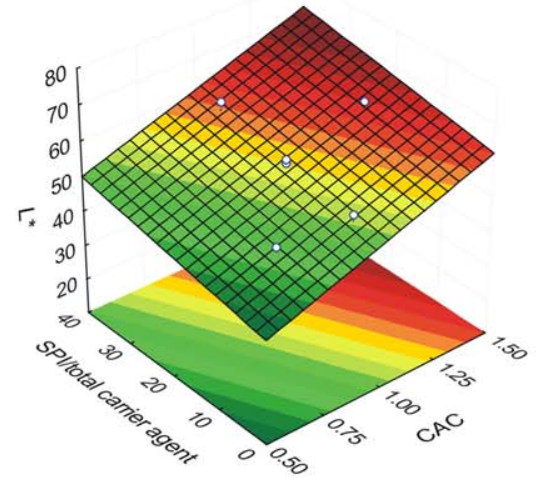

(b)

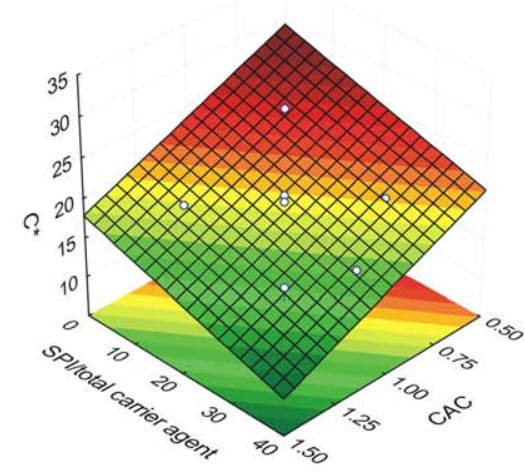

(d)

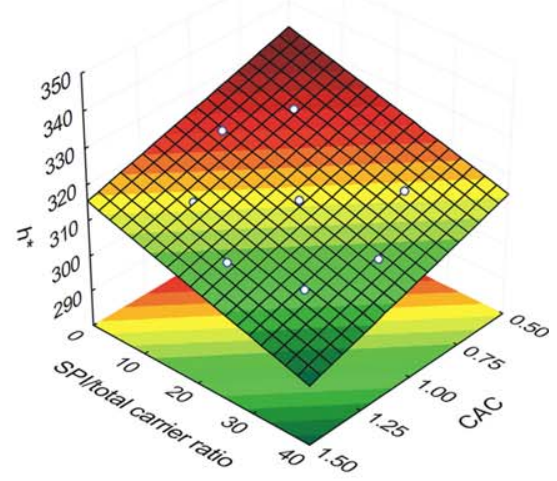

(f) hue angles and that this effect was more accentuated for blends SM than WM.

\section{Comparison Between Color of Powdered and Reconstituted Juices}

Considering that most applications of juice powder involve solubilization in water, it is relevant to evaluate the effects of $\mathrm{CAC}$ and $R$ on juice color after powder reconstitution. Four samples of juice powders, selected with basis on best global results for yield, anthocyanin retention and EE (Table 1), were reconstituted in water and had their color compared with fresh grape juice (Table 4 ). The $\Delta E^{\star}<1.5$ is considered small, indicating that the sample is almost identical to the original by visual observation. For $1.5 \leq \Delta E^{\star} \leq 5$, the color difference can already be distinguished, and this difference becomes evident for $\Delta E^{*}>5$ (Obón et al. 2009). The reconstituted samples $4 \mathrm{WM}$ and $6 \mathrm{WM}$ resulted in $\Delta E^{\star}>5$ (Table 
TABLE 3. ANALYSIS OF VARIANCE (ANOVA) OF THE MATHEMATICAL MODELS FOR $L^{*}, C^{*}$ AND $H^{*}$ FOR SAMPLES PRODUCED WITH WM AND SM BLENDS

\begin{tabular}{|c|c|c|c|c|c|c|c|c|}
\hline \multirow[b]{2}{*}{ Source of variation } & \multicolumn{2}{|c|}{ Sum of squares } & \multicolumn{2}{|c|}{$\begin{array}{l}\text { Degrees of } \\
\text { freedom }\end{array}$} & \multicolumn{2}{|c|}{ Mean square } & \multicolumn{2}{|c|}{$F$ calculated } \\
\hline & WM & SM & WM & SM & WM & SM & WM & SM \\
\hline & $L^{*}$ & & & & & & & \\
\hline Regression & 643.16 & 303.53 & & & 643.16 & 303.53 & 356.53 & 71.38 \\
\hline Residue & 14.43 & 34.02 & & & 1.80 & 4.25 & & \\
\hline \multirow[t]{2}{*}{ Total SS } & 657.59 & 337.55 & & & & & & \\
\hline & $C^{*}$ & & & & & & & \\
\hline Regression & 46.87 & 98.39 & & & 46.87 & 98.39 & 34.08 & 111.37 \\
\hline Residue & 11.00 & 7.07 & & & 1.37 & 0.88 & & \\
\hline \multirow[t]{2}{*}{ Total SS } & 57.87 & 105.46 & & & & & & \\
\hline & $h^{\star}$ & & & & & & & \\
\hline Regression & 472.77 & 334.14 & & & 472.77 & 334.14 & 287.91 & 259.09 \\
\hline Residue & 13.14 & 10.32 & & & 1.64 & 1.29 & & \\
\hline Total SS & 485.91 & 344.46 & & & & & & \\
\hline
\end{tabular}

Value $F$ critical $=5.32$

4), indicating visual differences in color of reconstituted juice compared with fresh juice. Nevertheless, samples 3SM and 7SM resulted in $\Delta E^{*}<5$, demonstrating that SM blends had lower influence on juice coloration, which may be attributed either to lower interference of SPI than WPC on reconstituted juice color or to better protection of anthocyanins by SPI than WPC during drying. Yousefi et al. (2011) stated that the coloring agent of pomegranate juice might have being absorbed into the carrier agent and being protected from severe damage during spray drying.

\section{Microstructure of Powder Particles}

Powders produced using WM blends showed much agglomeration (Fig. 4A), probably caused by stickiness. Particles were not spherical and some of them presented wrinkled surface, although there was no evidence of indentation or apparent pores. Sample $6 \mathrm{WM}$, corresponding to the greatest CAC (0.85) and intermediate $R(20 \%)$, resulted in the most suitable morphology when compared with other WM blends.

Lim et al. (2012) used whey protein/maltodextrin blends as wall material and obtained much agglomeration. Using only whey protein, other authors found no well-defined, agglomerated microcapsules (Bustos-Garza et al. 2013), or particles with deep dents and surface wrinkles (Baranauskiene et al. 2006). Regarding SM blends, SEM micrographs showed particles not completely spherical (Fig. $4 \mathrm{~B})$, but with higher sphericity than WM blends. There was some agglomeration (Fig. 4C) but it was possible to observe individual particles, in addition to wrinkled surfaces.

Carrier concentration was decisive when using blends SM. Samples 1SM, 2SM, and 5SM, which had lower CAC, showed poor ability of particle formation, whereas samples 3SM (Fig. 4B), 4SM and 6SM, with higher CAC, resulted in the most suitable particles. The presence of protein contributed considerably to particle agglomeration: sample $8 \mathrm{SM}$, with the highest $R(34.14 \%)$, resulted in higher agglomeration (Fig. 4C). Using soy protein, Deng et al. (2014) obtained particles with indented surface and wrinkled surface morphology. To soy protein with lactose, Tang and Li (2013) found high agglomeration and presence of dents.

Ferrari et al. (2012) and LIM et al. (2012) found that particles produced using only maltodextrin as drying aid showed smooth surface. Thus, it is possible to hypothesize that the irregularities observed in particle surface are due to

TABLE 4. COLOR COMPARISON BETWEEN FRESH, POWDERED AND RECONSTITUTED GRAPE JUICES

\begin{tabular}{|c|c|c|c|c|c|c|c|c|c|}
\hline \multirow[t]{2}{*}{ Sample } & \multirow[t]{2}{*}{$C A C^{*}$} & \multirow{2}{*}{$R^{\dagger}(\%)$} & $L^{*}$ & $a^{*}$ & $b^{*}$ & $L^{*}$ & $a^{*}$ & $b^{*}$ & \multirow[t]{2}{*}{$\Delta E^{\star}$} \\
\hline & & & \multicolumn{3}{|c|}{ Powdered juice } & \multicolumn{3}{|c|}{ Reconstituted juice } & \\
\hline $4 \mathrm{WM}$ & 0.75 & 30 & 57.12 & 11.11 & -11.17 & 13.32 & 8.56 & -8.36 & 15.14 \\
\hline $6 \mathrm{WM}$ & 0.85 & 20 & 51.45 & 15.19 & -10.31 & 7.61 & 8.33 & -6.16 & 9.76 \\
\hline $3 S M$ & 1.25 & 10 & 56.46 & 13.64 & -14.22 & 1.97 & 2.52 & -2.13 & 2.08 \\
\hline $7 S M$ & 1 & 5.86 & 51.77 & 16.71 & -11.99 & 1.44 & 2.24 & -1.35 & 1.57 \\
\hline Fresh juice & & & & & & 1.66 & 3.34 & -0.25 & \\
\hline
\end{tabular}

${ }^{\star} \mathrm{CAC}$ : $\mathrm{g}$ of carrier agent/g of soluble solids of the juice; ${ }^{\dagger} R(\%): \mathrm{g}$ dry protein/100 $\mathrm{g}$ dry carrier agent. 

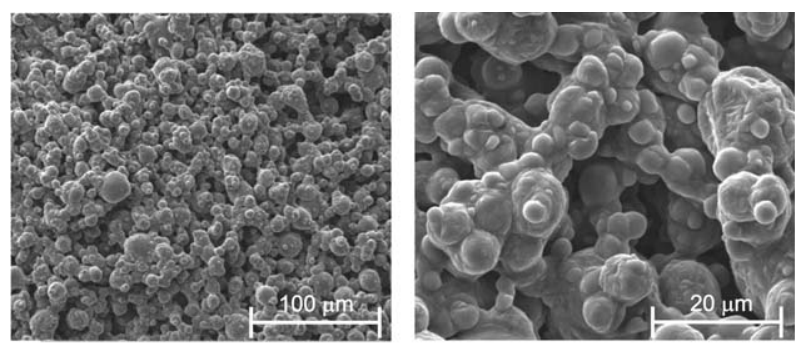

(a)
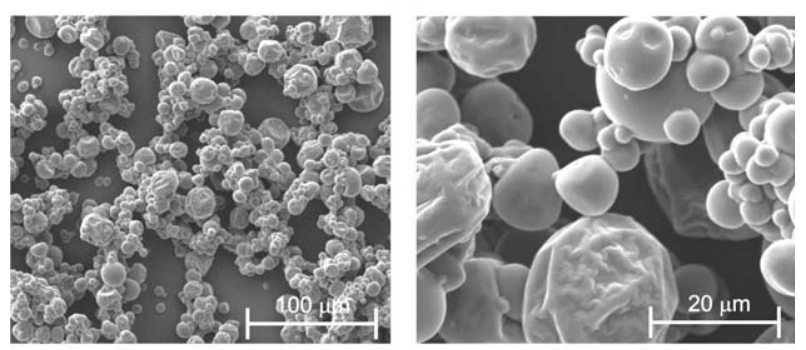

(b)
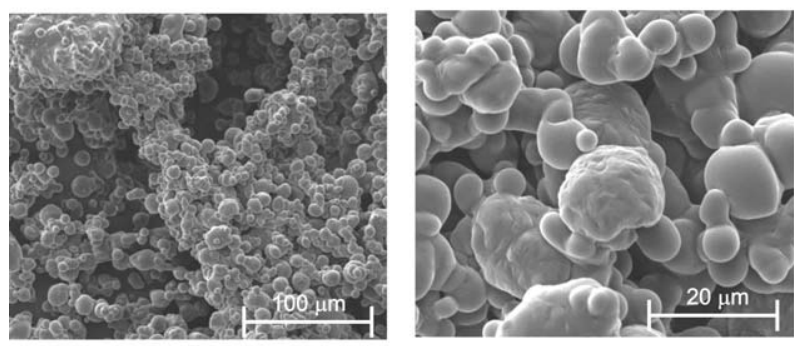

(c)

FIG. 4. SCANNING ELECTRON MICROSCOPIC IMAGES WITH MAGNIFICATION 1,000. (LEFT) AND 5,000 (RIGHT) OF POWDERED GRAPE JUICE MICROENCAPSULATED WITH: (A) 6WM; (B) 3SM; AND (C) $8 \mathrm{SM}$

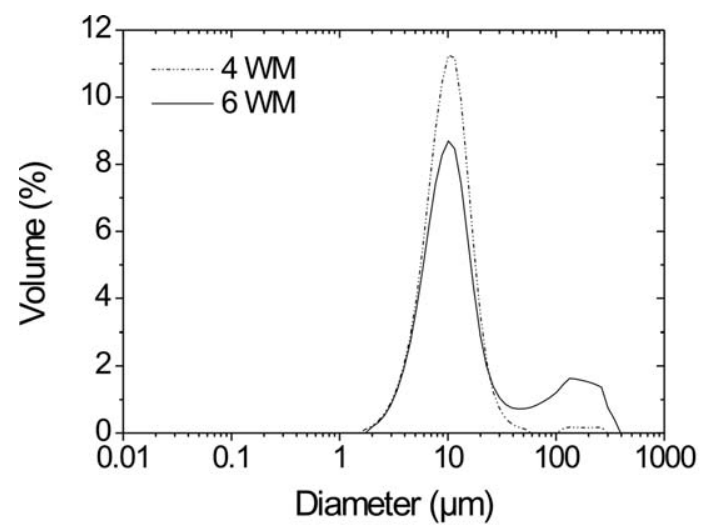

(a) presence of proteins in carrier formulations. Gharsallaoui et al. (2010) noted that in protein/carbohydrate blends, proteins serve as emulsifying and film-forming agents, while polysaccharides act as matrix forming material.

\section{Particle Size}

The powder formulations selected for reconstitution and color evaluation (4WM, 6WM, 3SM and 7SM), were also analyzed regarding particle size distributions. Sample $4 \mathrm{WM}$ $(\mathrm{CAC}=0.75 ; R=30 \%)$ presented unimodal size distribution (Fig. 5A), with diameters between 2 and $30 \mu \mathrm{m}$, and average diameter of $11.57 \mu \mathrm{m}$. On the other hand, sample $6 \mathrm{WM}(\mathrm{CAC}=0.85 ; R=20 \%)$ presented bimodal size distribution: the first peak included larger volume of particles $(>8 \%)$, with diameters between 2 and $30 \mu \mathrm{m}$, similar to sample $4 \mathrm{WM}$; the second peak enclosed lower volume of particles $(<2 \%)$ with size between 50 and $400 \mu \mathrm{m}$. The presence of larger particles can be attributed to agglomeration, which was previously observed by SEM. Particles 6WM showed average diameter of $34 \mu \mathrm{m}$.

Using maltodextrin, Tonon et al. (2010) obtained average diameter of $10.08 \mu \mathrm{m}$ to açai powder, whereas diameter of blackberry powder varied between 12.52 and $34.18 \mu \mathrm{m}$ (Ferrari et al. 2012). Bastos et al. (2012), using whey protein isolated obtained smaller particles $(6.17 \mu \mathrm{m})$. Carneiro et al. (2013), studying maltodextrin/WPC to spray drying flaxseed oil, observed wider size distribution $(0.02-160.0 \mu \mathrm{m})$.

The $3 \mathrm{SM}$ particles $(\mathrm{CAC}=1.25 ; R=10 \%)$ presented unimodal size distribution, with diameters between 1 and $40 \mu \mathrm{m}$ and average diameter of $12.49 \mu \mathrm{m}$ (Fig. 5B). Particles $7 \mathrm{SM} \quad(\mathrm{CAC}=1 ; \quad R=5.86 \%)$ presented bimodal size

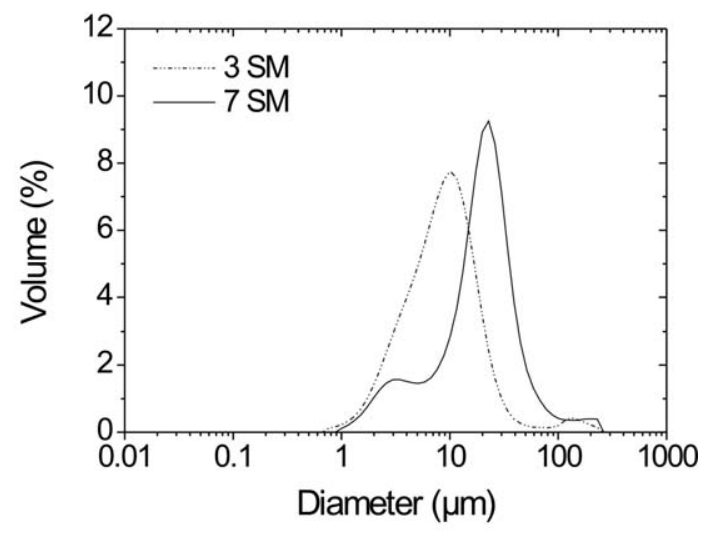

(b)

FIG. 5. PARTICLE SIZE DISTRIBUTIONS OF POWDERED GRAPE JUICE: (A) WPC/MALTODEXTRIN BLENDS, 4WM and 6WM; (B) SPI/MALTODEXTRIN BLENDS, 3SM and 7SM 
distribution: the first peak, partially superimposed to the second one, included small particle volume $(<2 \%)$ and small diameters, between 0.9 and $5 \mu \mathrm{m}$; the second peak presented greater volume $(>9 \%)$ and large size range, from 5 to $250 \mu \mathrm{m}$.

Molina Ortiz et al. (2009), encapsulating casein hydrolysate by spray drying with SPI also found bimodal size distribution, but smaller particle size $(11.32 \mu \mathrm{m})$.

\section{CONCLUSIONS}

The protein, WPC or SPI, used with maltodextrin to formulate carrier blends had different effects on properties of spray dried grape juice. Higher carrier concentrations resulted in higher yield and in higher particle sphericity, independently of the protein type. In addition, increasing carrier concentration, in general, leaded to better powder properties, such as increased anthocyanin retention with WPC/maltodextrin blends, and higher encapsulation efficiency with SPI/maltodextrin blends. Particles produced with WPC/maltodextrin presented some agglomeration, whereas SPI/maltodextrin resulted in particles that were more spherical, which could explain the higher encapsulation efficiency observed in these powders. Increasing carrier agent concentration and increasing ratio of protein/carrier agent resulted in brighter powders. Nevertheless, after reconstitution in water, the rehydrated juice presented color parameters similar to those of fresh juice, with better results for powders prepared with SPI/maltodextrin than WPC/ maltodextrin. In conclusion, whey and soy proteins blended with maltodextrin helped spray drying of grape juice, resulting in good retention and good encapsulating efficiency of anthocyanins. Spray dried grape juice powders are a promising food additive for incorporating anthocyanins of BRS Violeta grape into functional foods as well as developing innovative and healthy food products.

\section{ACKNOWLEDGMENTS}

To São Paulo Research Foundation (FAPESP) , grants 2012/ 09074-4 and 2010/09614-3 for the financial support, and Brazilian Agricultural Research Company - Grape and Wine (Jales, Brazil).

\section{REFERENCES}

ADHIKARI, B., HOWES, T., BHANDARI, B.R. and TROUNG, V. 2004. Effect of addition of maltodextrin on drying kinetics and stickiness of sugar and acid-rich foods during convective drying: Experiments and modelling. J. Food Eng. 62, 53-68.

ADHIKARI, B., HOWES, T., WOOD, B.J. and BHANDARI, B.R. 2009. The effect of low molecular weight surfactants and proteins on surface stickiness of sucrose during powder formation through spray drying. J. Food Eng. 94, 135-143.

BARANAUSKIENĖ, R., VENSKUTONIS, P.R., DEWETTINCK, K. and VERHÉ, R. 2006. Properties of oregano (Origanum vulgare L.), citronella (Cymbopogon nardus G.) and marjoram (Majorana hortensis L.) flavors encapsulated into milk protein-based matrices. Food Res. Int. 39, 413-425.

BASTOS, D.D.S., GONÇALVES, M.D.P., ANDRADE, C.T.D., ARAÚJO, K.G.D.L. and ROCHA LEÃO, M.H.M.D. 2012.

Microencapsulation of cashew apple (Anacardium occidentale, L.) juice using a new chitosan-commercial bovine whey protein isolate system in spray drying. Food Bioprod. Process. 90, 683-692.

BUSTOS-GARZA, C., YÁÑEZ-FERNÁNDEZ, J. and BARRAGÁN-HUERTA, B.E. 2013. Thermal and pH stability of spray-dried encapsulated astaxanthin oleoresin from Haematococcus pluvialis using several encapsulation wall materials. Food Res. Int. 54, 641-649.

CAMARGO, U.A., MAIA, J.D.G., NACHTIGAL, J.C. 2005. BRS VIOLETA Nova Cultivar de Uva para Suco e Vinho de Mesa, Embrapa Uva e Vinho (Comunicado Técnico, 63), Bento Gonçalves. CANO-CHAUCA, M., STRINGHETA, P.C., RAMOS, A.M. and CAL-VIDAL, J. 2005. Effect of the carriers on the microstructure of mango powder obtained by spray drying and its functional characterization. Innov. Food Sci. Emerg. Technol. 6, 420-428.

CARNEIRO, H.C.F., TONON, R.V., GROSSO, C.R.F. and HUBINGER, M.D. 2013. Encapsulation efficiency and oxidative stability of flaxseed oil microencapsulated by spray drying using different combinations of wall materials. J. Food Eng. 115, 443-451.

DENG, X.-X., CHEN, Z., HUANG, Q., FU, X. and TANG, C.-H. 2014. Spray-drying microencapsulation of $\beta$-carotene by soy protein isolate and/or OSA-modified starch. J. Appl. Polym. Sci. 131, 40399.

DUONGTHINGOC, D., GEORGE, P., KATOPO, L., GORCZYCA, E. and KASAPIS, S. 2013. Effect of whey protein agglomeration on spray dried microcapsules containing Saccharomyces boulardii. Food Chem. 141, 1782-1788.

FANG, Z. and BHANDARI, B. 2012. Comparing the efficiency of protein and maltodextrin on spray drying of bayberry juice. Food Res. Int. 48, 478-483.

FANG, Z., WANG, R. and BHANDARI, B. 2013. Effects of type and concentration of proteins on the recovery of spray-dried sucrose powder. Drying Technol. 31, 1643-1652.

FERRARI, C.C., GERMER, S.P.M. and DE AGUIRRE, J.M. 2012. Effects of spray-drying conditions on the physicochemical properties of blackberry powder. Drying Technol. 30, 154-163.

FRANCIS, F.J. 1982. Analysis of anthocyanins. In Anthocyanins as Food Colors (P. Markakis, ed.), Academic Press, New York. GHARSALLAOUI, A., SAUREL, R., CHAMBIN, O., CASES, E., VOILLEY, A. and CAYOT, P. 2010. Utilisation of pectin coating to enhance spray-dry stability of pea 
protein-stabilised oil-in-water emulsions. Food Chem. 122, 447-454.

JYOTHI, N.V., PRASANNA, P.M., SAKARKAR, S.N., PRABHA, K.S., RAMAIAH, P.S. and SRAWAN, G.Y. 2010. Microencapsulation techniques, factors influencing encapsulation efficiency. J Microencapsul. 27, 187-197.

KHA, T.C., NGUYEN, M.H. and ROACH, P.D. 2010. Effects of spray drying conditions on the physicochemical and antioxidant properties of the Gac (Momordica cochinchinensis) fruit aril powder. J. Food Eng. 98, 385-392.

LIM, H.-K., TAN, C.-P., BAKAR, J. and NG, S.-P. 2012. Effects of different wall materials on the physicochemical properties and oxidative stability of spray-dried microencapsulated red-fleshed pitaya (hylocereus polyrhizus) seed oil. Food Bioprocess Technol. 5, 1220-1227.

MADENE, A., JACQUOT, M., SCHER, J. and DESOBRY, S. 2006. Flavour encapsulation and controlled release - a review. Int. J. Food Sci. Technol. 41, 1-21.

MILLQVIST-FUREBY, A., ELOFSSON, U. and BERGENSTÅHL, B. 2001. Surface composition of spray-dried milk protein-stabilised emulsions in relation to pre-heat treatment of proteins. Colloids Surf. B 21, 47-58.

MOLINA ORTIZ, S.E., MAURI, A., MONTERREY-QUINTERO, E.S., TRINDADE, M.A., SANTANA, A.S. and

FAVARO-TRINDADE, C.S. 2009. Production and properties of casein hydrolysate microencapsulated by spray drying with soybean protein isolate. LWT - Food Sci. Technol. 42, 919-923.

NAYAK, C.A. and RASTOGI, N.K. 2010. Effect of selected additives on microencapsulation of anthocyanin by spray drying. Drying Technol. 28, 1396-1404.

NESTERENKO, A., ALRIC, I., SILVESTRE, F. and DURRIEU, V. 2012. Influence of soy protein's structural modifications on their microencapsulation properties: $\alpha$-Tocopherol microparticle preparation. Food Res. Int. 48, 387-396.

NESTERENKO, A., ALRIC, I., SILVESTRE, F. and DURRIEU, V. 2013a. Vegetable proteins in microencapsulation: A review of recent interventions and their effectiveness. Ind. Crops Prod. 42, 469-479.

NESTERENKO, A., ALRIC, I., VIOLLEAU, F., SILVESTRE, F. and DURRIEU, V. 2013b. A new way of valorizing biomaterials: The use of sunflower protein for $\alpha$-tocopherol microencapsulation. Food Res. Int. 53, 115-124.

NORI, M.P., FAVARO-TRINDADE, C.S., MATIAS DE ALENCAR, S., THOMAZINI, M., DE CAMARGO BALIEIRO, J.C. and CONTRERAS CASTILLO, C.J. 2011. Microencapsulation of propolis extract by complex coacervation. LWT - Food Sci. Technol. 44, 429-435.

OBÓN, J.M., CASTELLAR, M.R., ALACID, M. and FERNÁNDEZ-LÓPEZ, J.A. 2009. Production of a red-purple food colorant from Opuntia stricta fruits by spray drying and its application in food model systems. J. Food Eng. 90, 471-479.

PHISUT, N. 2012. Spray drying technique of fruit juice powder: Some factors influencing the properties of product. Int. Food Res. J. 19, 1297-1306.

REBELLO, L.P.G., LAGO-VANZELA, E.S., BARCIA, M.T., RAMOS, A.M., STRINGHETA, P.C., DA-SILVA, R., CASTILLO-MUÑOZ, N., GÓMEZ-ALONSO, S. and HERMOSÍN-GUTIÉRREZ, I. 2013. Phenolic composition of the berry parts of hybrid grape cultivar BRS Violeta (BRS Rubea $\times$ IAC 1398-21) using HPLC-DAD-ESI-MS/MS. Food Res. Int. 54, 354-366.

ROBERT, P., GORENA, T., ROMERO, N., SEPULVEDA, E., CHAVEZ, J. and SAENZ, C. 2010. Encapsulation of polyphenols and anthocyanins from pomegranate (Punica granatum) by spray drying. Int. J. Food Sci. Technol. 45, 1386-1394.

TANG, C.-H. and LI, X.-R. 2013. Microencapsulation properties of soy protein isolate: Influence of preheating and/or blending with lactose. J. Food Eng. 117, 281-290.

TELIS, V.R.N. and MARTÍNEZ-NAVARRETE, N. 2010. Application of compression test in analysis of mechanical and color changes in grapefruit juice powder as related to glass transition and water activity. LWT - Food Sci. Technol. 43, 744-751.

TELIS, V.R.N. and MARTÍNEZ-NAVARRETE, N. 2012. Biopolymers used as drying aids in spray-drying and freeze-drying of fruit juices and pulps. In Biopolymer Engineering in Food Processing (V.R.N. Telis, ed.) pp. 279-326, CRC Press, Boca Raton.

TONON, R.V., BRABET, C. and HUBINGER, M.D. 2009. Influência da temperatura do ar de secagem e da concentração de agente carreador sobre as propriedades físico-químicas do suco de açaí em pó. Food Sci. Technol. (Campinas) 29, 444-450.

TONON, R.V., BRABET, C. and HUBINGER, M.D. 2010. Anthocyanin stability and antioxidant activity of spray-dried açai (Euterpe oleracea Mart.) juice produced with different carrier agents. Food Res. Int. 43, 907-914.

WANG, R., ZHANG, M. and MUJUMDAR, A.S. 2010. Effect of food ingredient on microwave freeze drying of instant vegetable soup. LWT - Food Sci. Technol. 43, 1144-1150.

WROLSTAD, R.E. 1993. Color and pigment analyses in fruit products. Agric. Exp. Stn. 624, 1-17.

WROLSTAD, R.E. and CULVER, C.A. 2012. Alternatives to those artificial FD\&C food colorants. Annu. Rev. Food Sci. Technol. 3, 59-77.

YOUSEFI, S., EMAM-DJOMEH, Z. and MOUSAVI, S.M. 2011. Effect of carrier type and spray drying on the physicochemical properties of powdered and reconstituted pomegranate juice (Punica Granatum L.). J. Food Sci. Technol. 48, 677-684. 